International Journal of Oceans and Oceanography

ISSN 0973-2667 Volume 14, Number 1 (2020), pp. 9-16

(C) Research India Publications

https://dx.doi.org/10.37622/IJOO/14.1.2020.9-16

\title{
Study on distribution of Cysts of Harmful Algal Blooms-forming algae at Sohar Industrial Port, Sea of Oman
}

\author{
A. Al-Kharusi ${ }^{1 *}$, K.A. Al-Hashmi ${ }^{2}$, S. Dobrestov \\ ${ }^{1}$ Marine Science and Fisheries Center, Ministry of Agriculture and Fisheries \\ ${ }^{2}$ Sultan Qaboos University, Sultanate of Oman
}

\begin{abstract}
The current study focused on assessing the presence/absence of cysts of some harmful algal species in Sohar Industrial Port (SIP) and in the seawater intake basin of the desalination plant located in the Sea of Oman. A total of seven type's species of potential harmful dinoflagellate cysts species were identified inside Sohar Port and in its surrounding area, while no cysts were found in the intake area of the desalination plant. The presence of cysts-forming algae in the port and their absence from the intake site of the desalination plant indicates that the port is providing a suitable environment for their survival. $M$. polykrikoides cysts were found during the two periods of sampling indicating their establishment of population and may well pose serious threat to the desalination plant in the future.
\end{abstract}

Keywords: Harmful Algal Blooms; Sohar Industrial Port; Cysts of potential harmful dinoflagellate; Desalination plant; Sea of Oman

\section{INTRODUCTION}

The most diverse and abundant variety of phytoplankton groups are the dinoflagellates. Most dinoflagellates are known to cause outbreaks of harmful algal blooms in coastal waters around the world, and can be very toxic, leading to an extensive ecological impacts as well as wildlife and human health issues (Boerlage \& Nada, 2015; Pospelova 
\& Kim, 2010). Among approximately 2000 dinoflagellates species existing in marine ecosystem, there are around 200 species that form resting cysts as part of their life cycle (Joyce et al., 2005; Jung et al., 2018). These life stages form an important component of the ecology and distribution of dinoflagellates (Ellegaard et al., 1994). More than 16 cysts producing microalgal species are known to cause harmful algal blooms (HABs) and 7 species are toxic (Matsuoka et al., 2000). The ability to produce cysts is of a fundamental ecological importance to microalgal species; as it ensures their survival, facilitates the recurrence of HABs, and promotes their distribution (Matsuoka et al., 2000). Cysts are accumulated in the sediments where they remain sustainable for long periods of time until suitable conditions are available to bloom. (Joyce et al., 2005; Jung et al., 2018; Satta et al., 2013).

Cyst surveys provide historical data of harmful species distributed in a given area, and give an indication of future potential f blooms (Satta et al., 2013). This is the first attempt to investigate the presence of cysts of HABs-forming algae in the coastal water of Oman. The study was conducted at Sohar Industrial Port area (SIP) and in the seawater intake area in Sohar Industrial Area (SIPA) (Fig. 1). The Sohar Industrial Port Area is one of the largest industrial areas in Oman and holds a strategic place in the future development of the Sultanate.

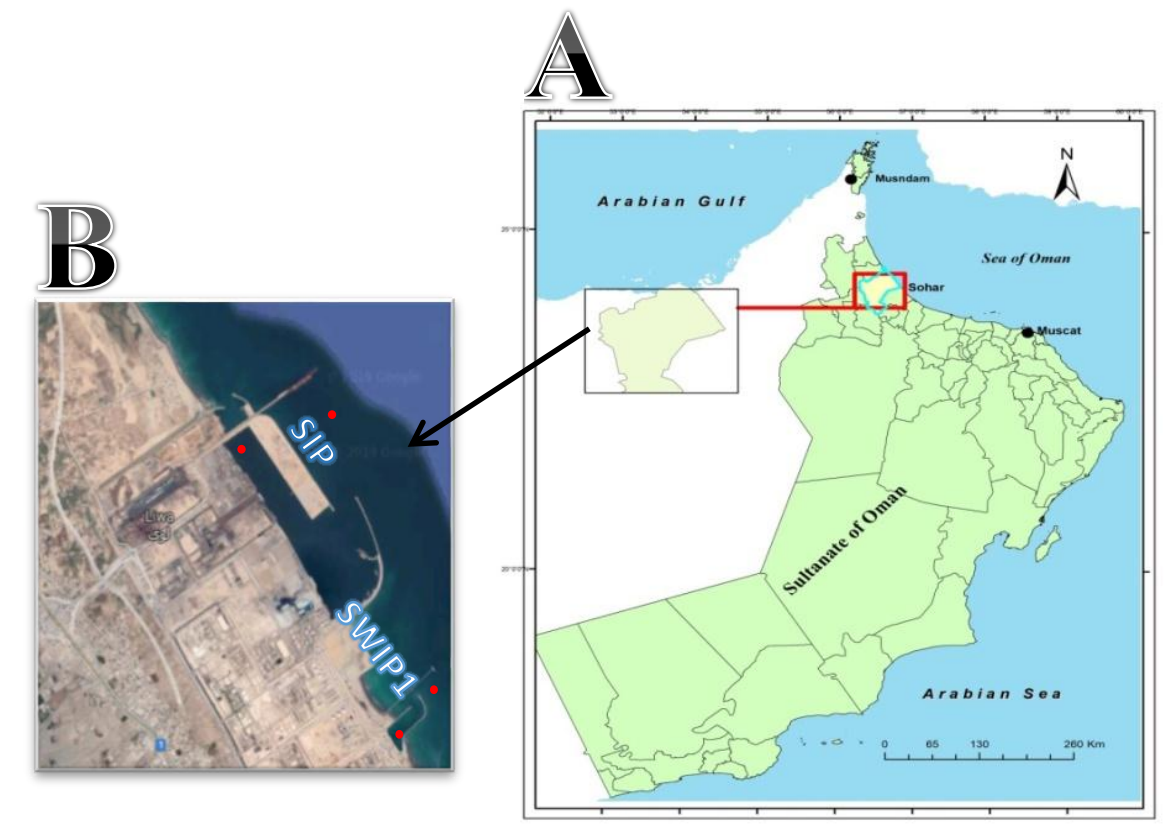

Figure 1. Study site location; A: Map of Oman; B: sampling area (SIP: Sohar Industrial Port, SWIPS: seawater intake pumping station), red dots show different sampling sites of sediments. 


\section{MATERIAL AND METHODS}

The study was conducted in Sohar Industrial area; Sohar Industrial Port (SIP) and in the seawater intake pumping station (SWIPS1) that belong to Majis Industrial Services Company (MISC) in the Sea of Oman (Fig. 1).

Sediment samples were collected on October, 2018 [n=4], and on March, $2019[n=5])$ from different sites located in SIP and from SWIPS (Fig. 1). Small core sampler $(\mathrm{d}=4$ $\mathrm{cm}$ ) was used to collect the sediment with the assistance of diver. Neutralized formalin (10\%) was used as fixing agent. Samples were then sieved using a series of sieves of various mesh-sizes with $125 \mu \mathrm{m}$ being the upper, $90 \mu \mathrm{m}$ in the middle and $38 \mu \mathrm{m}$ being the lowest sieve. All the residues on the $38 \mu \mathrm{m}$ sieve were transferred to separate small bottle for microscopic analysis using inverted microscope (Axiovert 25, ZEIZZ) equipped with objectives 40. Cysts identification was based on Matsuoka et al. (2000).

\section{RESULTS}

A total of seven type's species of potential harmful dinoflagellate cysts species were identified. Cysts were mostly dominated by potentially toxic dinoflagellates (Table.1, Fig.2). The Margalefidinium and Gymnodinium cysts were found during the two periods of sampling (October, 2018, and March, 2019). Other species were present only in March 2019. The sampling sites showed a similar cyst assemblage, but they differed in total cysts abundance (Table.1). Most of the cysts were found inside Sohar Port and the area surrounding it. No cysts were found in the seawater intake site.

Table 1: List of HAB cysts forming species found in Sohar Port and area surrounding it during two periods (October, 2018 and March, 2019)

\begin{tabular}{|c|l|l|}
\hline No. & Species & Site/Period \\
\hline 1 & Margalefidinium polykrikoides & $\begin{array}{l}\text { Inside \& outside port (October, 2018 \& } \\
\text { March, 2019) }\end{array}$ \\
\hline 2 & Gymnodinium catenatum & $\begin{array}{l}\text { Inside \& outside port (October, 2018 \& } \\
\text { March, 2019) }\end{array}$ \\
\hline 3 & Alexandrium spp. & Inside \& outside port (March, 2019) \\
\hline 4 & Gonyaulax spp. & Inside port ( March, 2019) \\
\hline 5 & Pyrodinium bahamense & Inside port ( March, 2019) \\
\hline 6 & Protoperidinium spp. & Inside port (March, 2019) \\
\hline 7 & Scrippsiella spp. & Inside port (March, 2019) \\
\hline
\end{tabular}




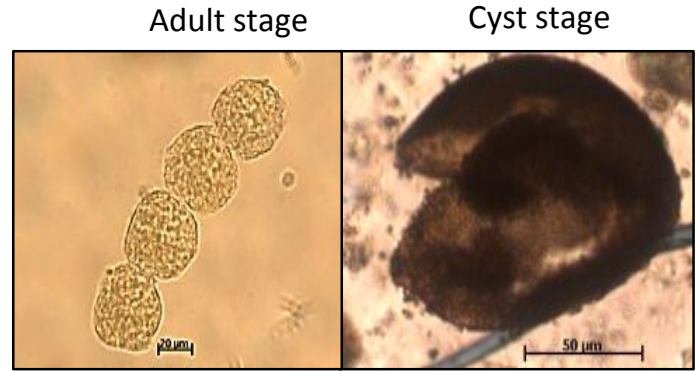

Gymnodinium catenatum

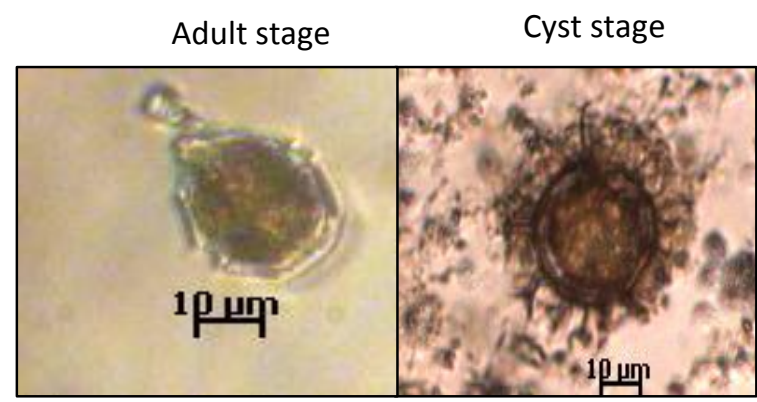

Gonyaulax spp.

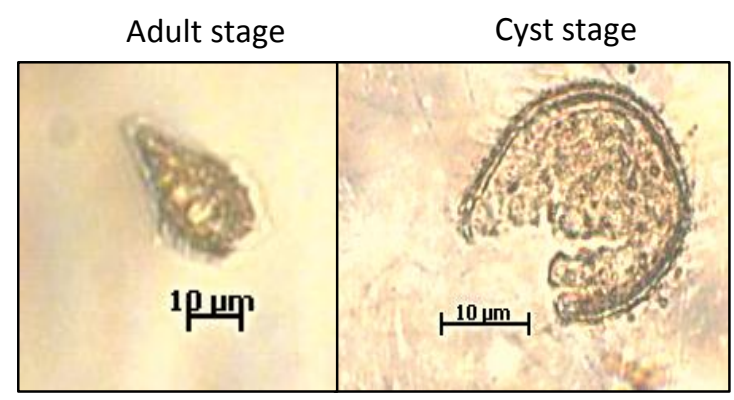

Scrippsiella spp.

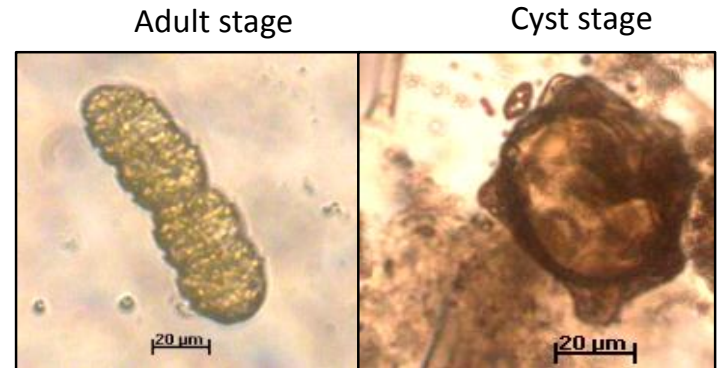

Margalefidinium polykrikoides

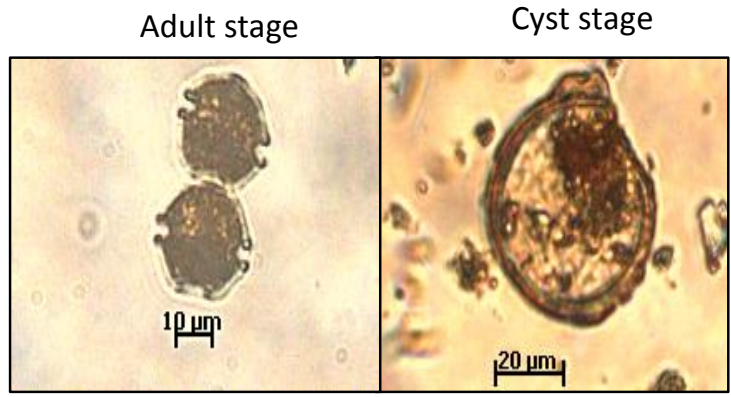

Alexandrium spp.

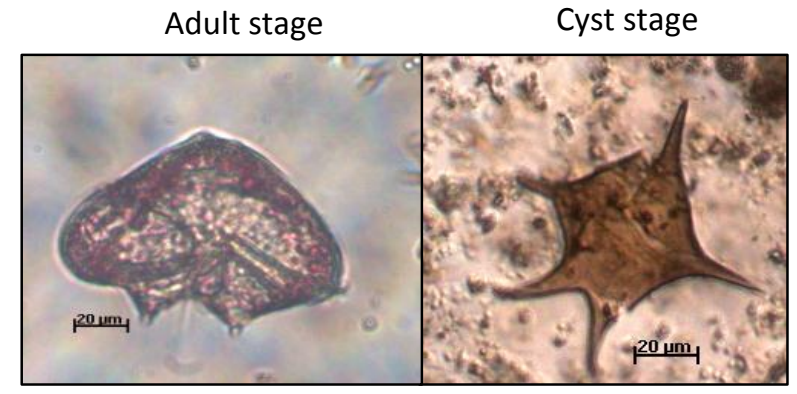

Protoperidinium spp.

Cyst stage

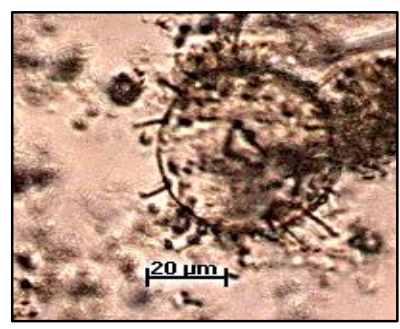

Pyrodinium bahamense

Figure 2: Images of cysts and adult stages of some HABs forming species found in Sohar Port and in the area surrounding during October, 2018 and March, 2019 


\section{DISCUSSION}

Dinoflagellate cysts in this study were only found inside Sohar Industrial Port (SIP) and its surrounding area and not in the seawater intake area of the desalination plant (SWIPS). This could be related to the muddy bottom of SIP compared to the sandy bottom of SWIPS. Anderson et al. (2003) demonstrated that most dinoflagellate cysts could survive in the muddy compare to the sandy one. This could be due to the fact that the dinoflagellate cysts depositional behavior is similar to that of fine particles, and that the abundance of dinoflagellates cysts increase in sediments with higher mud contents (Mohamed and Al-Shehri, 2011). Another reason, could be due to the availability of high percentage of organic content in muddy sediments than in sandy sediments (Kremp, 2000). Moreover, cyst could be introduced by ballast water since many ships are using the port for different purposes. Dinoflagellate cysts were introduced by the ballast tank sediments of ships that entering the ports in several countries in the world such as, Australia, New Zealand, America, Canada and Scotland (Nehring, 1995; Hamer et al., 2001). Also the highly disturbed bottom due to the continues intake of water, underwater operation such pipe installation, may contributed to the absence of cysts from the SWIPS. Cysts survive better in protected harbors and embayment than open coastal areas which are more exposed to wave and wind (Anderson et al., 2003). The persistent of M. polykrikoides cysts during the two periods of sampling (October, 2018, and March, 2019) at SIP, may explain the reason behind the bloom reoccurrence of this species in different time periods at the area. The first record of M. polykrikoides bloom in the coastal water of Oman was in September 2008 (Al Geilani et al., 2011; Al-Hashmi et al., 2014). The bloom occurred in late November 2008 and lasted until April causing severe ecological and economic impact on several recreations and environment resources including shut-down of desalination plants in the region (AlAzri et al., 2014). No bloom or presence of M. polykrikoides was recorded ever since in the coastal water of Oman. However in January, 2018, this species was found in blooming condition causing critical issues for seawater reverse osmosis desalination plants (SWRO). The ability of M. polykrikoides to form cyst and be in dormant stage till the conditions are favorable (Boerlage \& Nada, 2015; Richlen et al., 2010), will insure its continues appearance in Sohar industrial area and then along the coastal water of Oman. The major concern M. polykrikoides is not only its toxicity nature but major operational issues caused by the high biomass of algal cells and their mucilage which clogs the membranes of the water intake system (Boerlage \& Nada, 2015; Villacorte et al., 2015b).

\section{CONCLUSION AND RECOMMENDATIONS}

Cysts of seven HAB-forming species belonging to dinoflagellates were identified only at the SIP area, most of them are belong to potential toxic species. The presence of these $\mathrm{HAB}$ cysts-forming algae in the sediment samples taken from the port and their absence at the intake site of the desalination plant, indicates that the port is providing a suitable environment for the survival of these cysts and indicates their ability to bloom in future, if the proper environmental conditions are available. The persistent of M. polykrikoides 
cysts during the two periods of sampling indicate their establishment of population and could pose serious threat to the desalination plant.

The study recommends the importance of conducting study on cysts of HABs-forming algae ecology in combination with studying on the hydrodynamic, chemical and biological factors of marine habitats; in order to come up with comprehensive understanding of the spatial and temporal dynamics of dinoflagellates blooms. In addition, it is recommended to conduct cysts of HABs-forming algae surveys in other areas of Oman coast, including Sea of Oman and Arabian Sea. This information will help to predict and manage the formation of harmful algal blooms in the country.

\section{HIGHLIGHTS}

- A total of seven type's species of potential harmful dinoflagellate cysts species were identified.

- Cysts were mostly dominated by potentially toxic dinoflagellates.

- The Margalefidinium polykrikoides and Gymnodinium catenatum cysts were found during the two periods of sampling.

- Most of the cysts were found inside Sohar Port and the area surrounding it. No cysts were found in the seawater intake site.

- Most HABs cysts forming algae were found in muddy bottom of Sohar Industrial Port in comparison to the sandy bottom of Sea Water Intake Pumping Station (SWIPS).

- The presence of these HAB cysts-forming algae in the sediment samples taken from the port and their absence at the intake site of the desalination plant, indicates that the port is providing a suitable environment for the survival of these cysts and indicates their ability to bloom in future, if the proper environmental conditions are available.

\section{ACKNOWLEDGEMENTS}

This work was supported by Majis Industrial Services Company (Sultanate of Oman) and special thanks to Mr. Ahmed Al-Mazrooi (CEO of the company) and Mr. Abdullah Al-Sadi (Business Developer at the company) for providing the permit to access to their facility in particular and to Sohar Industrial Port in general. We would also like to acknowledge Mr. Adil Al-Qasmi, the diver at Sohar Industrial Port, who collected sediments samples. Thanks also to Dr. Hilal Al-Maqbali (Assistant professor at College of Applied Science-Sohar, Sultanate of Oman) for his help and suggestions.

\section{Declaration of interest}

The authors report no conflicts of interest. The authors alone are responsible for the content and writing of this article. 


\section{REFERENCES}

[1] Al-Azri, A. R., Piontkovski, S. A., Al-Hashmi, K. A., Goes, J. I., Gomes, H. D. R., \& Glibert, P. M., 2014. Mesoscale and nutrient conditions associated with the massive 2008 Cochlodinium polykrikoides bloom in the Sea of Oman/Arabian Gulf. Estuaries and coasts, 37(2), 325-338. Ecosystem Health \& Management, 15(sup1), 56-63.

[2] Al Gheilani, H. M., Matsuoka, K., AlKindi, A. Y., Amer, S., \& Waring, C., 2011. Fish kill incidents and harmful algal blooms in Omani waters. Journal of Agricultural and Marine Sciences [JAMS], 16, 23-33.

[3] Al-Hashmi, K. A., Goes, J., Claereboudt, M., Piontkovski, S. A., Al-Azri, A., \& Smith, S. L., 2014. Variability of dinoflagellates and diatoms in the surface waters of Muscat, Sea of Oman: comparison between enclosed and open ecosystem. International Journal of Oceans and Oceanography, 8(2), 137-152.

[4] Anderson, D. M., Fukuyo, Y., \& Matsuoka, K., 2003. Cyst methodologies. Manual on harmful marine microalgae, Monographs on oceanographic methodology, 11, 165-190.

[5] Boerlage, S., \& Nada, N., 2015. Algal toxin removal in seawater desalination processes. Desalination and Water Treatment, 55(10), 2575-2593.

[6] Ellegaard, M., Christensen, N. F., \& Moestrup, Ø. 1994. Dinoflagellate cysts from Recent Danish marine sediments. European Journal of Phycology, 29(3), 183-194.

[7] Hamer, J. P., Lucas, I. A. N., \& McCollln, T. A., 2001. Harmful dinoflagellate resting cysts in ships' ballast tank sediments: potential for introduction into English and Welsh waters. Phycologia, 40(3), 246-255.

[8] Joyce, L., Pitcher, G., Du Randt, A., \& Monteiro, P., 2005. Dinoflagellate cysts from surface sediments of Saldanha Bay, South Africa: an indication of the potential risk of harmful algal blooms. Harmful Algae, 4(2), 309-318.

[9] Jung, S. W., Kang, D., Kim, H. J., Shin, H. H., Park, J. S., Park, S. Y., \& Lee, T. K., 2018. Mapping distribution of cysts of recent dinoflagellate and Cochlodinium polykrikoides using next-generation sequencing and morphological approaches in South Sea, Korea. Scientific reports, 8(1), 7011.

[10] Kremp, A., 2000. Distribution, dynamics and in situ seeding potential of Scrippsiella hangoei (Dinophyceae) cyst populations from the Baltic Sea. Journal of Plankton Research, 22(11), 2155-2169.

[11] Matsuoka, K., \& Fukuyo, Y. A. S. U. W. O., 2000. Technical guide for modern dinoflagellate cyst study. WESTPAC-HAB, Japan Society for the Promotion of Science, Tokyo, Japan, 6-9.

[12] Mohamed, Z. A., \& Al-Shehri, A. M., 2011. Occurrence and germination of dinoflagellate cysts in surface sediments from the Red Sea off the coasts of Saudi Arabia. Oceanologia, 53(1), 121-136. 
[13] Nehring, S., 1995. Dinoflagellate resting cysts as factors in phytoplankton ecology of the North Sea. Helgoländer Meeresuntersuchungen, 49(1), 375.

[14] Pospelova, V., \& Kim, S. J., 2010. Dinoflagellate cysts in recent estuarine sediments from aquaculture sites of southern South Korea. Marine Micropaleontology, 76(1-2), 37-51.

[15] Richlen, M. L., Morton, S. L., Jamali, E. A., Rajan, A., \& Anderson, D. M., 2010. The catastrophic 2008-2009 red tide in the Arabian Gulf region, with observations on the identification and phylogeny of the fish-killing dinoflagellate Cochlodinium polykrikoides. Harmful Algae, 9(2), 163-172.

[16] Satta, C. T., Anglès, S., Lugliè, A., Guillén, J., Sechi, N., Camp, J., \& Garcés, E., 2013. Studies on dinoflagellate cyst assemblages in two estuarine Mediterranean bays: A useful tool for the discovery and mapping of harmful algal species. Harmful Algae, 24, 65-79. 